\title{
ANALISIS PERBANDINGAN KINERJA KEUANGAN DAN EKONOMI SOSIAL BANK SYARIAH ANTARA SEBELUM DAN SESUDAH DITETAPKANNYA FATWA MUI TENTANG HARAMNYA BUNGA BANK I)
}

\author{
Lia Auliah Rachmah \\ Program Studi S1 Ekonomi Islam-Fakultas Ekonomi dan Bisnis-Universitas Airlangga \\ Email : liaauliah31@gmail.com \\ Nisful Laila \\ Departemen Ekonomi Syariah- Fakultas Ekonomi dan Bisnis-Universitas Airlangga \\ Email : nisful.laila@gmail.com
}

\begin{abstract}
:
This study aims to find out the comparison between the performance of Islamic Banks including financial performances such as the ratio of ROA, ROE, FDR and CAR as wells economic and social performance such as MMR ratio before and after the determination of fatwa regarding the prohibition against bank interest. Quantitative approach and independent sample t-test has been used in this study. The data is a secondary data which was obtained by collecting the annual financial reports. The result of the independent sample t-test shows that there are significant differences between the performance of the Islamic banks before and after the fatwa on the ratio of ROE, FDR and MMR. Whereas on the ratio of ROA and CAR have no significant difference before and after the fatwa.

Keywords: comparison analysis, Islamic banks performances, fatwa Indonesian ulama council, regarding the prohibition of bank interest.
\end{abstract}

\section{PENDAHULUAN}

\section{Latar Belakang}

Bank syariah di Indonesia baru didirikan pada tahun 1990 melalui Tim Perbankan Majelis Ulama Indonesia (MUI). Tim ini menghasilkan berdirinya PT Bank Muamalat Indonesia (BMI) (Antonio, 2001:25). Bank Muamalat Indonesia merupakan pelopor berdirinya perbankan Islam yang lain yakni Bank Syariah Mandiri (BSM), Bank Mega Syariah Indonesia, BRI Syariah dan Panin Syariah. Bank Muamalat menjadi pioneer berdirinya perbankan Islam di Indonesia (Antonio, 2001:29).

Peranan Majelis Ulama Indonesia (MUI) dalam sejarah perkembangan perbankan syariah sangat penting.

Dukungan MUI ini antara lain terlihat dari berbagai peraturan mengenai kegiatan dan operasi perbankan syariah yang dikeluarkan oleh Bank Indonesia, lahir dari suatu proses setelah sebelumnya ditetapkan menjadi fatwa oleh Dewan Syariah Nasional, Majelis Ulama Indonesia. Dengan ditetapkannya fatwa tersebut menjadi Peraturan Bank Indonesia, tentunya akan memberikan kekuatan yang lebih mengikat bagi perbankan syariah dan pada gilirannya mempengaruhi perkembangan perbankan syariah didalam negeri (Ma'ruf 2008:18).

Pada tanggal 16 Desember 2003 diadakan Sidang ljtima Komisi Fatwa Majelis Ulama Indonesia dalam sidang tersebut memutuskan bahwa bunga bank adalah riba dan riba adalah hukumnya haram.

1) Jurnal ini merupakan bagian dari skripsi dari Lia Auliah Rachmah, NIM : 041211431032 , yang diuji pada 3 Juni 2016. 
Rachmah, et al/Jurnal Ekonomi Syariah Teori dan Terapan Vol. 3 No. 12 Desember 2016: 973-988; ANALISIS PERBANDINGAN KINERJA KEUANGAN DAN EKONOMI SOSIAL BANK SYARIAH ANTARA SEBELUM DAN SESUDAH DITETAPKANNYA FATWA MUI TENTANG HARAMNYA BUNGA BANK

Menurut Ma'ruf (2008:18) lahirnya

Fatwa MUI tentang pelarangan bunga bank adalah tuntutan dari masyarakat dengan tujuan memberikan motivasi dan dorongan terhadap perkembangan perbankan syariah di Indonesia.

Ahyar (2011:02) menyatakan bahwa tujuan dari keputusan Komisi Fatwa MUI tentang bunga bank haram adalah menjadi titik awal yang monumental dan fundamental untuk menggeser paradigma ekonomi kapitalis dan upaya mengurangi dominasi kapitalisme global serta kembali pada ekonomi yang sesuai dengan ajaran Islam. Kemungkinan pengaruh dan dampak positif dari Fatwa MUI diatas terhadap ekonomi perbankan syariah hanya bersifat sementara atau short-lived.

Pelarangan bunga yang ditetapkan melalui Keputusan Fatwa Majelis Ulama Indonesia Nomor 1 Tahun 2004 meliputi kegiatan baik yang dilakukan oleh bank, asuransi, pasar modal, pegadaian, koperasi dan lembaga keuangan lainnya maupun yang dilakukan oleh individu. Fatwa tersebut telah ditetapkan untuk dapat dijadikan pedoman dalam menjalankan kegiatan operasi perbankan syariah.

Berdasarkan teori tersebut tentu saja penetapan fatwa bahwa bunga bank haram diharapkan akan membawa implikasi yang positif bagi perbankan syariah. Fatwa ini diperkirakan akan meningkatkan kepercayaan masyarakat, terutama umat Muslim untuk menggunakan produk dan jasa perbankan syariah dalam aktivitas ekonomi (muamalah).

Pertumbuhan perbankan syariah yang pesat selalu diiringi dengan kinerja yang diterapkan pada bank syariah tersebut. Kinerja dalam bank syariah terbagi menjadi dua yaitu kinerja kevangan dan kinerja ekonomi sosial. Keduanya memerlukan pengukuran kinerja untuk melihat seberapa besar komitmen bank syariah dalam menjalankan kedua kinerja tersebut. Pengukuran kinerja bank juga bermanfaat sebagai alat evaluasi dalam menentukan kebijakan di masa depan dengan melihat kinerja di masa lalu. Seperti yang terkandung dalam Al Quran surat Al Hasyr ayat 18 sebagai berikut:

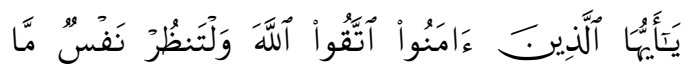

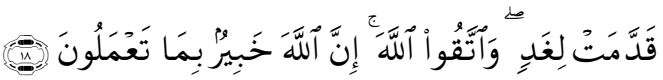

Artinya: "Hai orang-orang yang beriman, bertakwalah kepada Allah dan hendaklah setiap diri memperhatikan apa yang telah diperbuatnya untuk hari esok (akhirat); dan bertakwalah kepada Allah, Sesungguhnya Allah Maha mengetahui apa yang kamu kerjakan". (QS 59:18 Departemen Agama RI, 2011) Menurut P3El (2012:02) pemenuhan kinerja kevangan dan kinerja ekonomi sosial bank syariah merupakan inti dari ekonomi Islam yang mengajarkan kepada manusia asas keseimbangan antara kehidupan ritual dan sosial untuk mencapai kemulian (falah) sebagai tujuan hidup. Penilaian kinerja keuangan bank syariah sangat penting karena 
Rachmah, et al/Jurnal Ekonomi Syariah Teori dan Terapan Vol. 3 No. 12 Desember 2016: 973-988; ANALISIS PERBANDINGAN KINERJA KEUANGAN DAN EKONOMI SOSIAL BANK SYARIAH ANTARA SEBELUM DAN SESUDAH DITETAPKANNYA FATWA MUI TENTANG HARAMNYA BUNGA BANK

kinerja keuangan bank yang buruk menjadi awal dari tidak sehatnya suatu bank dan hal ini akan berdampak pada perekonomian suatu negara. Pengukuran kinerja keuangan bank syariah menggunakan analisis rasio profitabiliats, likuiditas dan permodalan yang berdasarkan rasio-rasio inti kesehatan bank syariah. Dan pengukuran kinerja ekonomi sosial menggunakan analisis pembiayaan (Mudharabah-Musyarakah Ratio).

Penelitian ini menggunakan Bank Umum Syariah yaitu Bank Muamalat dan Bank Syariah Mandiri. Pengambilan subjek penelitian ini didasari oleh data dari Bank Indonesia yang menyebutkan bahwa bank tersebut memilki total aset yang melebihi rata-rata dari total aset Bank Umum Syariah.

Tabel 1.

Total Aset Bank Umum Syariah (Dalam Jutaan Rupiah)

\begin{tabular}{|l|r|}
\hline \multicolumn{1}{|c|}{ Bank Umum Syariah } & \multicolumn{1}{|c|}{ Total Aset } \\
\hline Bank Syariah Mandiri & 66.942 .422 \\
Bank Muamalat & 62.413 .310 \\
Bank BRI Syariah & 20.343 .249 \\
Bank BNI Syariah & 19.492 .112 \\
Bank Mega Syariah & 7.042 .489 \\
Bank BCA Syariah & 2.994 .449 \\
\hline
\end{tabular}

Sumber: Hasil Penelitian, 2016 (diolah).

Bank Syariah Mandiri dan Bank Muamalat tersebut merupakan dua bank umum syariah yang menjadi awal kemunculan bank syariah di Indonesia. Pengambilan sampel kedua bank umum syariah tersebut juga berdasarkan tujuan dari penelitian ini yaitu untuk mengetahui perbedaan kinerja bank syariah antara sebelum dan sesudah fatwa MUI tentang haramnya bunga bank (studi pada Bank Muamalat Indonesia dan Bank Syariah Mandiri).

Berdasarkan latar belakang yang telah dipaparkan diatas, maka dapat diambil rumusan masalah pada penelitian ini, yaitu apakah terdapat perbedaan kinerja bank syariah sebelum dan sesudah ditetapaknnya Fatwa MUI tentang haramnya bunga bank (studi pada Bank Muamalat dan Bank Syariah Mandiri) dilihat dari rasio ROA, ROE, FDR, CAR dan MMR?

Adapun tujuan penelitian ini adalah untuk mengetahui perbedaan kinerja bank syariah sebelum dan sesudah ditetapaknnya Fatwa MUI tentang haramnya bunga bank (studi pada Bank Muamalat dan Bank Syariah Mandiri) dilihat dari rasio ROA, ROE, FDR, CAR dan MMR.

\section{Landasan Teori dan Pengembangan Hipotesis}

Muhammad (2011:15) bank Islam atau yang disebut bank syariah adalah bank yang beroperasi tanpa mengandalkan bunga, yang produknya dikembangkan berdasarkan Al-Qur'an dan Hadits Nabi SAW, atau dengan kata lain adalah lembaga kevangan yang usaha pokoknya serta peredaran vang yang pengoperasiannya disesuaikan dengan prinsip syariat Islam. Majelis Ulama Indonesia sudah menfatwakan bahwa seluruh transaksi diharamkan apabila mengandung unsur bunga. Menurut (Cholil, 2011:34) menyatakan bahwa 
Rachmah, et al/Jurnal Ekonomi Syariah Teori dan Terapan Vol. 3 No. 12 Desember 2016: 973-988; ANALISIS PERBANDINGAN KINERJA KEUANGAN DAN EKONOMI SOSIAL BANK SYARIAH ANTARA SEBELUM DAN SESUDAH DITETAPKANNYA FATWA MUI TENTANG HARAMNYA BUNGA BANK

Fatwa MUI juga merupakan sumber hukum pelaksanaan kegiatan perbankan syariah, yakni sebagai berikut:

a. Undang-Undang No. 21 Tahun 2008 tentang perbankan syariah mensyaratkan fatwa MUI sebagai salah satu dasar hukum yang wajib dipatuhi.

b. Salah satu perbedaan principal antara perbankan syariah dan konvensioanl, bahwa perbankan syariah dalam pelaksanaannya harus tunduk dan patuh pada syariah, dalam hal ini adalah fatwa MUI.

c. Kesesuaian fatwa MUI merupakan syarat yang paling mendasar dalam pembuatan dan pengembangan produk dan aktivitas baru yang akan dikeluarkan oleh bank.

Perkembangan perbankan syariah yang pesat selalu diiringi dengan pengukuran kinerja yang baik. Menurut Kusumo (2008) pengukuran kinerja sangat penting dilakukan untuk mengukur sejauh mana tingkat efisiensi dan efektivitas perusahaan dalam pencapaian tujuan perusahaan. Pengukuran kinerja dalam perbankan syariah antara lain kinerja keungan dan kinerja ekonomi sosial.

Kinerja keuangan yang digunakan dalam penelitian ini adalah rasio profitabilitas, rasio likuiditas dan rasio permodalan. Sedangkan untuk kinerja ekonomi sosial menggunakan rasio pembiayaan (MMR).

Menurut Dendawijaya (2009:114) rasio profitabilitas (earnimg) adalah rasio yang menunjukkan perbandingan anatara laba dengan aset. Rasio ini menunjukkan tingkat efektivitas dan profitabilitas yang dicapai melalui usaha operasional bank. Rasio profitabilitas dalam penelitian ini adalah Return on Asset (ROA) dan Return on Equity (ROE). Menurut Dendawijaya (2009: 117), suatu bank dikatakan likuid apabila bank tersebut dapat memenuhi kewajiban hutang-hutangnya, dapat membayar kembali semua depositonya, serta dapat memenuhi permintaan kredit yang diajukan tanpa terjadi penangguhan. Rasio likuiditas ini dilakukan untuk menganalisis kemampuan bank dalam memenuhi kewajiban-kewajibannya. Dalam penelitian ini rasio likuiditas yang digunakan adalah Financing to Deposit Ratio (FDR).

Bank pada umumnya dan bank syariah pada khusunya adalah lembaga yang didirikan dengan orientasi laba. Kekuatan aspek permodalan ini memungkinkan terbangunnya kondisi bank yang dipercaya oleh masyarakat. perhitungan penyediaan modal minimum atau kecukupan modal bank (Capital Adequacy) didasarkan pada rasio atau perbandingan antara modal yang dimiliki bank dengan jumlah Aktiva Tertimbang Menurut Resiko (ATMR). (Dendawijaya, 2005: 140). Dalam penelitian ini rasio permodalan yang digunakan adalah Capital Adequacy Ratio.

Lembaga keuangan Islam memilki dua fungsi utama, yaitu fungsi bisnis 
Rachmah, et al/Jurnal Ekonomi Syariah Teori dan Terapan Vol. 3 No. 12 Desember 2016: 973-988; ANALISIS PERBANDINGAN KINERJA KEUANGAN DAN EKONOMI SOSIAL BANK SYARIAH ANTARA SEBELUM DAN SESUDAH DITETAPKANNYA FATWA MUI TENTANG HARAMNYA BUNGA BANK

(tijarah) dan fungsi sosial (tabarru') (Ryandono, 2010:56). Menurut alJawziyyah (1995) kinerja sosial dalam Islam adalah suatu keharusan, karena dalam Islam aktivitas bisnis tidak dilakukan hanya untuk kepuasan serta kebutuhan materi dan keinginan saja tetapi hal yang lebih penting adalah seharusnya dilakukan untuk memenuhi perintah agama dan mencapai tujuan non materi seperti mengamankan kebutuhan sosial. Hal tersebut dapat dilihat dari adanya tata cara dan aturan ketika harus melakukan aktivitas yang berkaitan dengan kebutuhannya, dan juga terkait dengan pemanfaatan yang harus memilki tujuan maslahah. Hal ini tertuang dalam AlQur'an surat Al-An'am ayat 160 sebagai berikut:

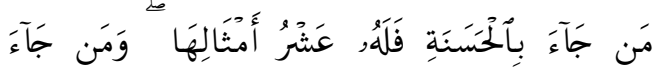

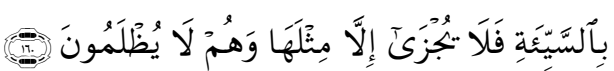

Artinya: "Barangsiapa membawa amal yang baik, maka baginya (pahala) sepuluh kali lipat amalnya, dan barangsiapa yang membawa perbuatan jahat maka dia tidak diberi pembalaswan melainkan seimbang dengan kejahatannya, sedang mereka sedikitpun tidak dianiaya (dirugikan)." (Departemen Agama, 2005:150).

Berdasarkan UU No. 21 Tahun 2008

Tentang Perbankan Syariah dalam pasal 4 disebutkan bahwa selain berkewajiban untuk menghimpun dan menyalurkan dana pada masyarakat, Bank Syariah dan Unit Usaha Syariah dapat menjalankan fungsi sosial dalam bentuk pembiayaan seperti, pembiayaan Mudharabah Musyarakah. Selain itu, bank syariah juga menerima dana yang berasal dari Zakat, Infaq, Shadaqah, hibah atau dana sosial lainnya.

Melalui pendekatan indikator di atas, maka dalam penelitian ini penulis hanya menggunakan 1 variabel untuk mengukur kinerja ekonomi sosial bank syariah yakni rasio pembiayaan Mudharabah Musyarakah Ratio (MMR).

Menurut Beik (2007) bahwa skema pembiayaan mudharabah-musyarakah akan memberikan manfaat positif bagi perekonomian Indonesia diantaranya dalah menggairahkan sektor rill. Investasi akan meningkat yang disertai dengan pembukaan lapangan kerja baru. Dampaknya, tingkat pengangguran dapat dikurangi dan pendapatan masyarakat akan bertambah. Dengan demikian, bank syariah dapat berperan lebih signifikan dalam upaya mengatasi permasalahan ekonomi Indonesia. Oleh karena itu, pembiayaan mudharabahmusyarakah dapat dijadikan sebagai pengukur dari kinerja sosial bank syariah.

Berdasarkan penelitian yang dilakukan Bayu (2014) bahwa terdapat perbedan profitabilitas bank syariah sebelum dan sesudah adanya fatwa MUI. Sehingga hipotesis penelitian ini dengan $\mathrm{H} 1$ yaitu Terdapat perbedaan signifikan kinerja kevangan dan kinerja ekonomi sosial sebelum dan sesudah dikeluarkannya fatwa MUI tentang haramnya bunga bank (studi pada Bank Muamalat Indonesia dan Bank Syariah Mandiri) dengan menggunakan rasio 
Rachmah, et al/Jurnal Ekonomi Syariah Teori dan Terapan Vol. 3 No. 12 Desember 2016: 973-988; ANALISIS PERBANDINGAN KINERJA KEUANGAN DAN EKONOMI SOSIAL BANK SYARIAH ANTARA SEBELUM DAN SESUDAH DITETAPKANNYA FATWA MUI TENTANG HARAMNYA BUNGA BANK

dilihat dari ROA, ROE, FDR, CAR, dan MMR. Sebelum melakukan uji hipotesis, dilakukan uji normalitas. Model analisis yang digunakan adalah independent sample t-test untuk menemukan adakah perbedaan kinerja kevangan dan kinerja ekonomi sosial antara sebelum dan sesudah dikeluarkannya fatwa MUI tentang haramnya bunga bank (studi pada Bank Muamalat Indonesia dan Bank Syariah Mandiri).

\section{METODE PENELITIAN}

Penelitian ini menggunakan metode kuantitatif komparatif dengan tujuan analisis uji hipotesis. variabelvariabel yang digunakan dalam penelitian ini adalah:

1. Return On Assets (ROA)

2. Return On Equity (ROE)

3. Financing Deposit Ratio (FDR)

4. Capital Adequacy Rasio (CAR)

5. Mudharabah-Musyarakah Ratio (MMR).

\section{Definisi Operasional}

Definisi operasional dari variabel yang digunakan dalam penelitian ini adalah sebagai berikut:

\section{Return On Assets (ROA)}

ROA bertujuan untuk mengukur kemampuan bank syariah dalam memperoleh keuntungan (laba sebelum pajak) yang diperoleh dari total aset yang dimiliki bank tersebut. ROA dihitung dengan persamaan berikut:

$$
\mathrm{ROA}=\frac{\text { Laba sebelum pajak }}{\text { Total asset }} \times 100 \%
$$

2. Return On Equity (ROE)

ROE bertujuan untuk mengukur tingkat keuntungan bersih yang dihasilkan oleh satu unit Rp modal bank syariah. ROE dihitung dengan persamaan berikut:

$$
\mathrm{ROE}=\frac{\text { Laba setelah pajak }}{\text { Modal sendiri }}
$$

3. Financing Deposit Ratio (FDR)

FDR bertujuan untuk mengukur seluruh jumlah pembiayaan yang diberikan bank dengan dana yang diterima oleh bank. FDR dihitung dengan persamaan berikut:

$$
\text { FDR }=\frac{\text { Pembiayaan }}{\text { Total dana pihak ketiga }} \times 100 \%
$$

\section{$\times 100 \%$}

4. Capital Adequacy Ratio (CAR)

CAR bertujuan untuk mengukur kemampuan bank syariah dalam menjaga kecukupan modal. CAR dihitung dengan persamaan berikut:

$$
\text { CAR }=\frac{\text { Modal }}{\text { ATMR }} \times 100 \%
$$

5. Mudharabah-Musyarakah Ratio (MMR) MMR bertujuan untuk mengukur total pembiayaan berakad mudaharabah dan musyarakah dibandingkan dengan total pembiayaannya. MMR dihitung dengan persamaan berikut:

$$
\frac{M M R=\text { Mudharabah }+ \text { Musyarakah }}{\text { Total Financing }} \times 100 \%
$$


Rachmah, et al/Jurnal Ekonomi Syariah Teori dan Terapan Vol. 3 No. 12 Desember 2016: 973-988; ANALISIS PERBANDINGAN KINERJA KEUANGAN DAN EKONOMI SOSIAL BANK SYARIAH ANTARA SEBELUM DAN SESUDAH DITETAPKANNYA FATWA MUI TENTANG HARAMNYA BUNGA BANK

Jenis dan Sumber Data

Jenis data yang digunakan dalam penelitian ini adalah data sekunder. "Data sekunder adalah data yang diperoleh dari sumber kedua atau sumber sekunder data yang kita butuhkan" (Bungin, 2005:122). Sumber data sekunder dalam penelitian ini berupa laporan kevangan dari Bank Muamalat Indonesia dan Bank Syariah Mandiri pada periode 1999-2014. Data yang digunakan adalah data time series, yaitu nilai variabel yang berurutan menurut waktu dengan data tahunan pada periode 1999-2014. Serta juga terdapat referensi lain dari jurnal maupun hasil penelitian yang berkaitan dengan penelitian ini.

\section{Populasi dan Sampel}

Pada penelitian ini populasinya adalah Bank Muamalat Indonesia dan Bnak Syariah Mandiri. Teknik pengambilan sampel yang digunakan adalah purposive sampling. Purposive sampling adalah teknik penentuan sampel dengan pertimbangan tertentu (Anshori dan Iswati, 2009 : 105). Kriteria dalam pengambilan sampel pada penelitian ini adalah sebagai berikut :

1. Bank Umum Syariah Nasional Devisa yang memilki aset terbesar di Indonesia.

2. Bank Muamalat dan Bank Syariah Mandiri yang mempublikasikan laporan tahunan secara berturut-turut selama periode penelitian. Adapun periode penelitian yaitu selama periode sebelum fatwa yaitu tahun
1999-2003, dan sesudah fatwa dikeluarkan pada tahun 2005-2014.

3. Bank Muamalat dan Bank Syariah Mandiri mempunyai semua data yang diperlukan secara lengkap, yang mencakup kinerja bank syariah. Dimana kinerja tersebut dapat tersebut dapat dianalaisis dari neraca dan laporan laba rugi.

\section{Teknik Analisis Data}

Metode analisis yang digunakan untuk melakukan pengujian hipotesis penelitian ini adalah parametric t-test (independent sampel t-test) bila sampel terdistribusi normal dan non-parametricsigned-rank test (Mann-Whitney test) bila sampel tidak terdistribusi normal. Langkahlangkah yang harus dilakukan sebelum pengujian hipotesis adalah:

1. Menghitung besarnya rasio ROA, ROE, FDR, CAR, dan MMR dalam penelitian ini.

2. Membandingkan secara langsung kinerja Bank Muamalat dan Bank Syariah Mandiri sebelum dan sesudah fatwa MUI dengan menghitung selisih dua rata-rata (mean).

3. Uji Normalitas

Sebelum melakukan uji hipotesis, harus melakukan uji One Sample Kolmogorov-Smirnov Test terhadap seluruh data untuk melihat distribusi data normal atau tidak (Santoso, 2010:210). Data yang terdistribusi normal akan ditandai dengan Asymp. sig (2 tailed) > 0,05 maka data berdistribusi normal. 
Rachmah, et al/Jurnal Ekonomi Syariah Teori dan Terapan Vol. 3 No. 12 Desember 2016: 973-988; ANALISIS PERBANDINGAN KINERJA KEUANGAN DAN EKONOMI SOSIAL BANK SYARIAH ANTARA SEBELUM DAN SESUDAH DITETAPKANNYA FATWA MUI TENTANG HARAMNYA BUNGA BANK

4. Uji Beda

Uji yang digunakan adalah parametric t-test (independent sampel t-test). Uji ini adalah bagian dari statistik parametrik yang digunakan untuk membandingkan dua grup yang tidak berhubungan dengan data distribusi normal sehingga dapat diketahui apakah kedua grup tersebut memiliki rata-rata yang sama atau tidak (Sujarweni, 2014:97). Terdapat dua langkah untuk melakukan uji ini yaitu:

a. Menentukan $\dagger$ hitung menggunakan equal variances assumed atau equal variances non assumed. Pengambilan keputusan dari $F$ hitung adalah:

1. Jika nilai sig $F$ hitung $\geq 0,05$ maka Ho diterima, sehingga kedua varian opulasi identik (equal variances assumed).

2. Jika nilai sig $F$ hitung $\leq 0,05$ maka Ho ditolak, sehingga kedua varian populasi tidak identik (equal variances non assumed).

b. Pengambilan keputusan dari $\dagger$ hitung adalah:

1. Jika nilai sig $\nmid \geq$ dari 0,05 maka Ho diterima.

2. Jika nilai sig $\dagger \leq$ dari 0,05 maka Ho ditolak.
IV. HASIL DAN PEMBAHASAN Deskripsi Return On Assets (ROA)

Tabel 2.

Perbandingan Rata-Rata ROA Bank Muamalat dan Bank Syariah Mandiri sebelum dan sesudah Fatwa MUI. (Dalam Persentase)

\begin{tabular}{|c|c|c|}
\hline Periode & $\begin{array}{c}\text { Bank } \\
\text { Muamalat }\end{array}$ & $\begin{array}{c}\text { Bank Syariah } \\
\text { Mandiri }\end{array}$ \\
\hline Sebelum & 1,78 & 1,72 \\
\hline Sesudah & 1,99 & 1,96 \\
\hline
\end{tabular}

Sumber : Hasil Penelitian, 2016 (diolah)

Dari tabel dapat diketahui bahwa rata-rata Return On Asset (ROA) yang dimiliki Bank Muamalat sebelum Fatwa sebesar $1,78 \%$, sedangkan sesudah Fatwa ROA naik 0,21\% menjadi 1,99\%. Dan Bank Syariah Mandiri rata-rata ROA sebelum Fatwa sebesar $1,72 \%$, sedangkan sesudah Fatwa ROA naik menjadi $0,24 \%$ menjadi 1,96\%. Maka rata-rata Return On Asset (ROA) Bank Syariah Mandiri lebih baik jika dibandingkan Bank Muamalat ketika sesudah Fatwa MUI.

\section{Deskripsi Return On Equity (ROE)} Tabel 3.

Perbandingan Rata-Rata ROE Bank Muamalat dan Bank Syariah Mandiri sebelum dan sesudah Fatwa MUI. (Dalam Persentase)

\begin{tabular}{|c|c|c|}
\hline Periode & $\begin{array}{c}\text { Bank } \\
\text { Muamalat }\end{array}$ & $\begin{array}{c}\text { Bank Syariah } \\
\text { Mandiri }\end{array}$ \\
\hline Sebelum & 16,23 & 3,67 \\
\hline Sesudah & 18,58 & 25,55 \\
\hline
\end{tabular}

Sumber : Hasil Penelitian, 2016 (diolah)

Dari tabel dapat diketahui bahwa rata-rata Return On Equity (ROE) yang dimiliki Bank Muamalat sebelum Fatwa sebesar 16,23\%, sedangkan sesudah Fatwa ROE naik 2,35\% menjadi $18,58 \%$. Dan Bank Syariah Mandiri rata-rata ROA 
Rachmah, et al/Jurnal Ekonomi Syariah Teori dan Terapan Vol. 3 No. 12 Desember 2016: 973-988; ANALISIS PERBANDINGAN KINERJA KEUANGAN DAN EKONOMI SOSIAL BANK SYARIAH ANTARA SEBELUM DAN SESUDAH DITETAPKANNYA FATWA MUI TENTANG HARAMNYA BUNGA BANK

sebelum Fatwa sebesar 3,67\%, sedangkan sesudah Fatwa ROA naik menjadi $21,88 \%$ menjadi 25,55\%. Maka rata-rata Return On Equity (ROE) Bank Syariah Mandiri lebih baik jika dibandingkan Bank Muamalat ketika sesudah Fatwa MUI.

\section{Deskripsi Financing Deposit Ratio (FDR)}

Tabel 4.

Perbandingan Rata-Rata FDR

Bank Muamalat dan Bank Syariah Mandiri sebelum dan sesudah Fatwa MUI. (Dalam Persentase)

\begin{tabular}{|c|c|c|}
\hline Periode & $\begin{array}{c}\text { Bank } \\
\text { Muamalat }\end{array}$ & $\begin{array}{c}\text { Bank Syariah } \\
\text { Mandiri }\end{array}$ \\
\hline Sebelum & 83,32 & 59,58 \\
\hline Sesudah & 91,70 & 87,29 \\
\hline
\end{tabular}

Sumber : Hasil Penelitian, 2016 (diolah)

Dari tabel dapat diketahui bahwa rata-rata Financing Deposit Ratio (FDR) yang dimiliki Bank Muamalat sebelum Fatwa sebesar 83,32\%, sedangkan sesudah Fatwa FDR naik $8,38 \%$ menjadi 91,70\%. Dan Bank Syariah Mandiri ratarata FDR sebelum Fatwa sebesar 59,58\%, sedangkan sesudah Fatwa FDR naik menjadi $27,71 \%$ menjadi $87,29 \%$. Maka rata-rata Financing Deposit Ratio (FDR) Bank Syariah Mandiri lebih baik jika dibandingkan Bank Muamalat ketika sesudah Fatwa MUI.

\section{Deskripsi Capital Adequancy Ratio (CAR)}

Tabel 5.

Perabndingan Rata-Rata CAR

Bank Muamalat dan Bank Syariah Mandiri sebelum dan sesudah Fatwa MUI.

\begin{tabular}{|c|c|c|}
\multicolumn{2}{c|}{ (Dalam Persentase) } \\
\hline Periode & $\begin{array}{c}\text { Bank } \\
\text { Muamalat }\end{array}$ & $\begin{array}{c}\text { Bank Syariah } \\
\text { Mandiri }\end{array}$ \\
\hline Sebelum & 11,37 & 12,70 \\
\hline Sesudah & 13,14 & 12,98 \\
\hline
\end{tabular}

Sumber : Hasil Penelitian, 2016 (diolah)
Dari tabel dapat diketahui bahwa rata-rata Capital Adequancy Ratio (CAR) yang dimiliki Bank Muamalat sebelum Fatwa sebesar 11,37\%, sedangkan sesudah Fatwa CAR naik $1,77 \%$ menjadi 13,14\%. Dan Bank Syariah Mandiri ratarata CAR sebelum Fatwa sebesar 12,70\%, sedangkan sesudah Fatwa CAR naik menjadi $0,27 \%$ menjadi $12,97 \%$. Maka ratarata Capital Adequancy Ratio (CAR) Bank Muamalat lebih baik jika dibandingkan Bank Syariah Mandiri ketika sesudah Fatwa MUI.

\section{Deskripsi Mudharabah Musyarakah Ratio (MMR)}

Tabel 6.

Analisis Statistik Deskriptif MMR Bank Muamalat dan Bank Syariah Mandiri sebelum dan sesudah Fatwa MUI. (Dalam Persentase)

\begin{tabular}{|c|c|c|}
\hline Periode & $\begin{array}{c}\text { Bank } \\
\text { Muamalat }\end{array}$ & $\begin{array}{c}\text { Bank Syariah } \\
\text { Mandiri }\end{array}$ \\
\hline Sebelum & 9,98 & 6,81 \\
\hline Sesudah & 45,24 & 30,34 \\
\hline
\end{tabular}

Sumber : Hasil Penelitian, 2016 (diolah)

Dari tabel dapat diketahui bahwa rata-rata Mudharabah Musyarakah Ratio (MMR) yang dimiliki Bank Muamalat sebelum Fatwa sebesar 9,98\%, sedangkan sesudah Fatwa MMR naik 35,26\% menjadi 45,24\%. Dan Bank Syariah Mandiri ratarata MMR sebelum Fatwa sebesar 6,81\%, sedangkan sesudah Fatwa MMR naik menjadi $23,53 \%$ menjadi 30,34\%. Maka rata-rata Mudharabah Musyarakah Ratio (MMR) Bank Muamalat lebih baik jika dibandingkan Bank Syariah Mandiri ketika sesudah Fatwa MUI. 
Rachmah, et al/Jurnal Ekonomi Syariah Teori dan Terapan Vol. 3 No. 12 Desember 2016: 973-988; ANALISIS PERBANDINGAN KINERJA KEUANGAN DAN EKONOMI SOSIAL BANK SYARIAH ANTARA SEBELUM DAN SESUDAH DITETAPKANNYA FATWA MUI TENTANG HARAMNYA BUNGA BANK

Uji Normalitas

Uji normalitas perlu dilakukan bahwa data terdistribusi normal. Apabila hasil pengujian normalitas menyatakan data terdistribusi normal, maka dilakukan pengujian independent sampel t-test. Pengujian normalitas dilakukan pada variabel ROA, ROE, FDR, CAR dan MMR pada periode sebelum dan sesudah Fatwa MUI. Tingkat signifikasi yang digunakan sebesar $(\alpha)=5 \%(0,05)$.

Tabel 7.

Hasil Uji Normalitas One Sample Kolmogorov-Smirnov Test

\begin{tabular}{|l|l|l|l|}
\hline Periode & Variabel & \multicolumn{1}{|c|}{ Sig. } & Hasil \\
\hline \multirow{3}{*}{$\begin{array}{l}\text { Sebelum } \\
\text { Fatwa }\end{array}$} & ROA & 0,723 & Normal \\
\cline { 2 - 4 } & ROE & 0,333 & Normal \\
\cline { 2 - 4 } & FDR & 0,560 & Normal \\
\cline { 2 - 4 } & CAR & 0,999 & Normal \\
\cline { 2 - 4 } & MMR & 0,594 & Normal \\
\hline \multirow{3}{*}{$\begin{array}{l}\text { Sesudah } \\
\text { Fatwa }\end{array}$} & ROA & 0,744 & Normal \\
\cline { 2 - 4 } MUI & ROE & 0,756 & Normal \\
\cline { 2 - 4 } & FDR & 0,718 & Normal \\
\cline { 2 - 4 } & CAR & 0,852 & Normal \\
\cline { 2 - 4 } & MMR & 0,892 & Normal \\
\hline
\end{tabular}

Sumber : Hasil Penelitian, 2016 (diolah)

Berdasarkan tabel diatas, dapat diketahui bahwa seluruh data variabel terdistribusi secara normal berdasarkan nilai signifikasinya. Hasil uji normalitas terhadap variabel ROA, ROE, FDR, CAR, dan MMR pada periode sebelum dan sesudah Fatwa MUI Tentang Haramnya Bunga Bank dinyatakan normal. Pengambilan keputusan tersebut berdasarkan pada nilai signifikasi yang dimiliki oleh masing-masing variabel setelah dilakukan uji normalitas. Data pada variabel ROA, ROE, FDR, CAR, dan MMR berdistribusi normal saat nilai signifikasi berada diatas 0,05 maka dapat menggunakan pengujian hipotesis parametric t-test (independent sampel ttest).

\section{Uji Hipotesis}

Pengujian hipotesis dengan independent sample t-test menggunakan tingkat signifikansi $5 \%(0,05)$. Apabila hasil perhitungan independent sample t-test menunjukkan nilai sig. lebih dari atau sama dengan tingkat signifikansi $(0,05)$, maka $\mathrm{H}_{0}$ diterima, yang berarti tidak terdapat perbedaan yang signifikan kinerja bank syariah antara sebelum dan sesudah Fatwa MUI tentang haramnya bunga bank Apabila hasil perhitungan dengan independent sample t-test menunjukkan nilai sig. kurang dari tingkat signifikansi $(0,05)$, maka $\mathrm{H}_{0}$ ditolak dan $\mathrm{H}_{1}$ diterima yang berarti terdapat perbedaan yang signifikan kinerja bank syariah antara sebelum dan sesudah Fatwa MUI tentang haramnya bunga bank.

Tabel 8.

Uji Independent Sample t-test

\begin{tabular}{|l|c|l|l|}
\hline Rasio & Sig. & Keputusan & Kesimpulan \\
\hline ROA & 0,624 & $\begin{array}{l}\mathrm{H}_{0} \\
\text { diterima }\end{array}$ & $\begin{array}{l}\text { Tidak } \\
\text { terdapat } \\
\text { perbedaan }\end{array}$ \\
\hline ROE & 0,013 & $\mathrm{H}_{0}$ ditolak & $\begin{array}{l}\text { Terdapat } \\
\text { perbedaan }\end{array}$ \\
\hline FDR & 0,047 & $\mathrm{H}_{0}$ ditolak & $\begin{array}{l}\text { Terdapat } \\
\text { perbedaan }\end{array}$ \\
\hline CAR & 0,577 & $\begin{array}{l}\mathrm{H}_{0} \\
\text { diterima }\end{array}$ & $\begin{array}{l}\text { Tidak } \\
\text { terdapat } \\
\text { perbedaan }\end{array}$ \\
\hline MMR & 0,000 & $\mathrm{H}_{0}$ ditolak & $\begin{array}{l}\text { Terdapat } \\
\text { perbedaan }\end{array}$ \\
\hline
\end{tabular}

Sumber : Hasil Penelitian, 2016 (diolah)

Hasil uji Independent Sample t-test menunjukkan bahwa variabel ROE, FDR, dan MMR mempunyai nilai sig. < 0,05 
Rachmah, et al/Jurnal Ekonomi Syariah Teori dan Terapan Vol. 3 No. 12 Desember 2016: 973-988; ANALISIS PERBANDINGAN KINERJA KEUANGAN DAN EKONOMI SOSIAL BANK SYARIAH ANTARA SEBELUM DAN SESUDAH DITETAPKANNYA FATWA MUI TENTANG HARAMNYA BUNGA BANK

sehingga keputusan dari uji hipotesis bahwa $\mathrm{H}_{0}$ ditolak dan $\mathrm{H}_{1}$ diterima. Hasil pengujian ini menunjukkan bahwa terdapat perbedaan yang signifikan kinerja bank syariah dari segi ROE, FDR, dan MMR antara sebelum dan sesudah Fatwa MUI tentang haramnya bunga bank. Sedangkan pada variabel ROA dan CAR mempunyai nilai sig. $>0,05$ sehingga keputusan dari uji hipotesis adalah $\mathrm{H}_{0}$ diterima. Maka tidak terdapat perbedaan yang signifikan kinerja bank syariah dari segi ROA dan CAR antara sebelum dan sesudah Fatwa MUI tentang haramnya bunga bank.

\section{Pembahasan}

Return on Assets (ROA) Bank Syariah antara Sebelum dan Sesudah Fatwa MUI Tentang Haramnya Bunga Bank

Berdasarkan uji yang telah dilakukan, dapat dinyatakan bahwa dari kedua Bank Umum Syariah tersebut ternyata tidak terdapat perbedaan kinerja dari segi rasio ROA antara sebelum dan sesudah Fatwa MUI tentang haramnya bunga bank. Penelitian ini mendukung penelitian yang dilakukan oleh Fatih (2014) yang menunjukkan bahwa tidak terdapat perbedaan kinerja keuangan pada rasio ROA. Gambar terkait perkembangan rasio ROA antara sebelum dan sesudah Fatwa MUI pada Bank Umum Syariah dapat terlihar di gambar 1:

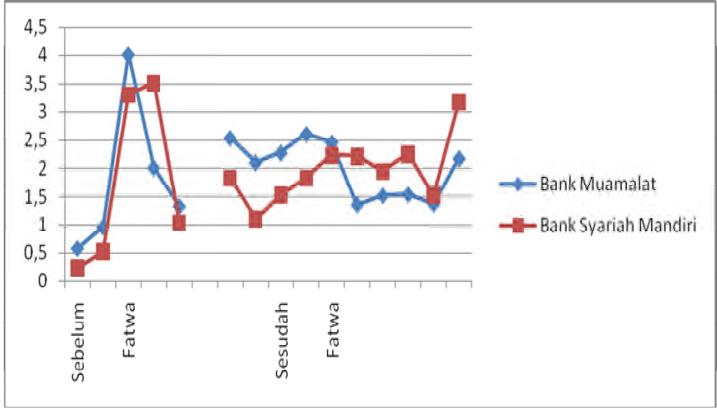

Sumber : Hasil Penelitian, 2016 (diolah)

Gambar 1.

Perkembangan Rasio ROA Bank Muamalat dan Bank Syariah Mandiri antara sebelum dan sesudah Fatwa MUI tentang haramnya bunga bank Tidak terdapatnya perbedaan kinerja dari segi ROA antara sebelum dan sesudah Fatwa MUI didasarkan pada gambar 1 menunjukkan bahwa saat sebelum Fatwa terdapat nilai rasio ROA yang dibawah 1,5\%. Padahal Bank Indonesia telah menetapkan bahwa bank yang beroperasi di Indonesia harus memiliki rasio ROA dengan nilai minimum sebesar 1,5\%. Begitu pula pada saat sesudah Fatwa masih terdapat nilai rasio ROA dibawah standar minimal yang ditetapkan oleh Bank Indonesia yakni sebesar $1,5 \%$.

Return on Equity (ROE) Bank Syariah antara Sebelum dan Sesudah Fatwa MUI Tentang Haramnya Bunga Bank

Berdasarkan uji yang telah dilakukan, dapat dinyatakan bahwa dari kedua Bank Umum Syariah tersebut terdapat perbedaan kinerja keuangan dari segi rasio ROE antara sebelum dan sesudah Fatwa MUI tentang haramnya bunga bank. Hal ini disebabkan kerena naiknya pendapatan Bank Syariah sesudah ditetapkannya Fatwa MUI. Hal ini 
Rachmah, et al/Jurnal Ekonomi Syariah Teori dan Terapan Vol. 3 No. 12 Desember 2016: 973-988; ANALISIS PERBANDINGAN KINERJA KEUANGAN DAN EKONOMI SOSIAL BANK SYARIAH ANTARA SEBELUM DAN SESUDAH DITETAPKANNYA FATWA MUI TENTANG HARAMNYA BUNGA BANK

dikarenakan masyarakat mulai memberi kepercayaan terhadap bank syariah, terutama umat muslim untuk menggunakan produk dan jasa perbankan syariah setelah ditetapkannya Fatwa MUI, sehingga semakin banyaknya nasabah bank syariah tersebut maka akan semakin meningkatkan pendapatan yang diperoleh bank syariah. Perbandingan ROE dan Pendapatan bank syariah bisa dilihat pada gambar 2 berikut ini:

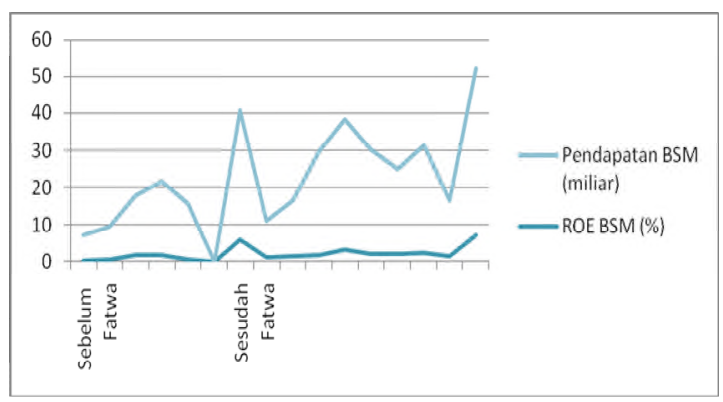

Sumber : Hasil Penelitian, 2016 (diolah)

Gambar 2.

Perbandingan ROE dan Pendapatan Bank Syariah antara sebelum dan sesudah Fatwa MUI tentang haramnya bunga bank

\section{Financing Deposit Ratio (FDR) Bank Syariah antara Sebelum dan Sesudah Fatwa MUI Tentang Haramnya Bunga Bank}

Berdasarkan uji yang telah dilakukan, dapat dinyatakan bahwa dari kedua Bank Umum Syariah tersebut terdapat perbedaan kinerja dari segi rasio FDR antara sebelum dan sesudah Fatwa MUI tentang haramnya bunga bank. Penelitian ini didukung oleh penelitian yang dilakukan Fatih (2014). Perbedaan yang signifikan ini disebabkan pada saat sesudah Fatwa MUI Bank Syariah lebih ekspansif dalam melakukan pembiayaan dibandingkan sebelum Fatwa MUI. Sehingga terjadi peningkatan yang signifikan pada rasio FDR. Adapun pertumbuhan dana pihak ketiga dan pembiayaan yang dimiliki oleh bank syariah dapat dilihat pada gambar 3 sebagai berikut:

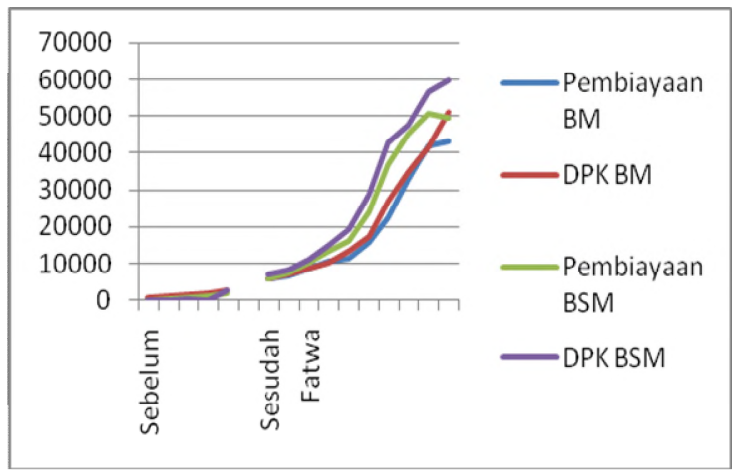

Sumber: Hasil Penelitian, 2016 (diolah)

Gambar 3.

Dana Pihak Ketiga dan Pembiayaan Bank Muamalat dan Bank Syariah Mandiri antara sebelum dan sesudah Fatwa MUI tentang haramnya bunga bank

\section{Capital Adequacy Ratio (CAR) Bank Syariah antara Sebelum dan Sesudah Fatwa MUI Tentang Haramnya Bunga Bank}

Berdasarkan uji yang telah dilakukan, dapat dinyatakan bahwa dari kedua Bank Umum Syariah tersebut tidak terdapat perbedaan kinerja dari segi rasio CAR antara sebelum dan sesudah Fatwa MUI tentang haramnya bunga bank. Penelitian ini bertentangan dengan Fadlili (2012). Gambar terkait perkembangan rasio CAR antara sebelum dan sesudah Fatwa MUI dapat dilihat pada gambar 4: 
Rachmah, et al/Jurnal Ekonomi Syariah Teori dan Terapan Vol. 3 No. 12 Desember 2016: 973-988; ANALISIS PERBANDINGAN KINERJA KEUANGAN DAN EKONOMI SOSIAL BANK SYARIAH ANTARA SEBELUM DAN SESUDAH DITETAPKANNYA FATWA MUI TENTANG HARAMNYA BUNGA BANK

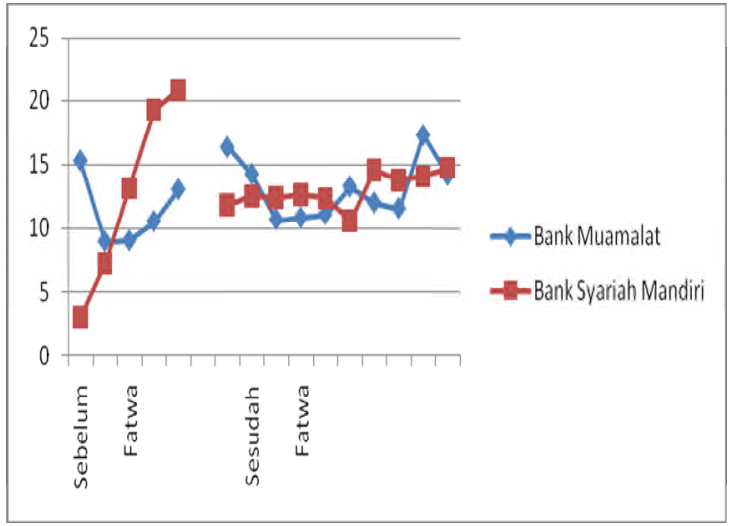

Sumber: Hasil Penelitian, 2016 (diolah) Gambar 4.

Perkembangan Rasio CAR Bank Muamalat dan Bank Syariah Mandiri antara sebelum dan sesudah Fatwa MUI tentang haramnya bunga bank

Tidak terdapat perbedaan dari segi rasio CAR pada Kedua Bank Umum Syariah tersebut disebabkan oleh besarnya selisih antara periode sebelum dan sesudah Fatwa MUI yang dapat terlihat pada gambar 4. Hasil yang menunjukkan tidak terdapatnya perbedaan pada rasio CAR yang dimiliki Kedua Bank Umum Syariah antara sebelum dan sesudah Fatwa MUI juga disebabkan oleh adanya ketentuan dari Bank Indonesia bahwa bank yang beroperasi di Indonesia harus memiliki rasio CAR dengan nilai minimum sebesar 8\%. Sehingga Kedua Bank Umum Syariah anatra sebelum dan sesudah Fatwa MUI berupaya untuk dapat memenuhi standar tersebut.

\section{Mudharabah-Musyarakah Ratio (MMR)}

Bank Syariah antara Sebelum dan Sesudah Fatwa MUI Tentang Haramnya Bunga Bank

Berdasarkan uji yang telah dilakukan, dapat dinyatakan bahwa dari kedua Bank Umum Syariah tersebut terdapat perbedaan kinerja ekonomi dan sosial dari segi rasio MMR antara sebelum dan sesudah Fatwa MUI tentang haramnya bunga bank. Penelitian ini bertentangan dengan penelitian yang dilakukan Yuliani (2012) yang menyatakan bahwa MMR tidak terdapat perebedaan yang signifikan.

Perbedaan yang signifikan

disebabkan persentase antara pembiayaan Mudharabah Musyarakah yang semakin meningkat jika dibandingkan sebelum Fatwa MUI, ini berrati kedua Bank Umum Syariah memiliki komitmen yang tinggi dalam memberdayakan ekonomi umat. Adapun pertumbuhan pembiayaan Mudharabah Musyarakah yang dimiliki oleh Bank Muamalat dan Bank Syariah Mandiri dapat dilihat pada gambar 5 .

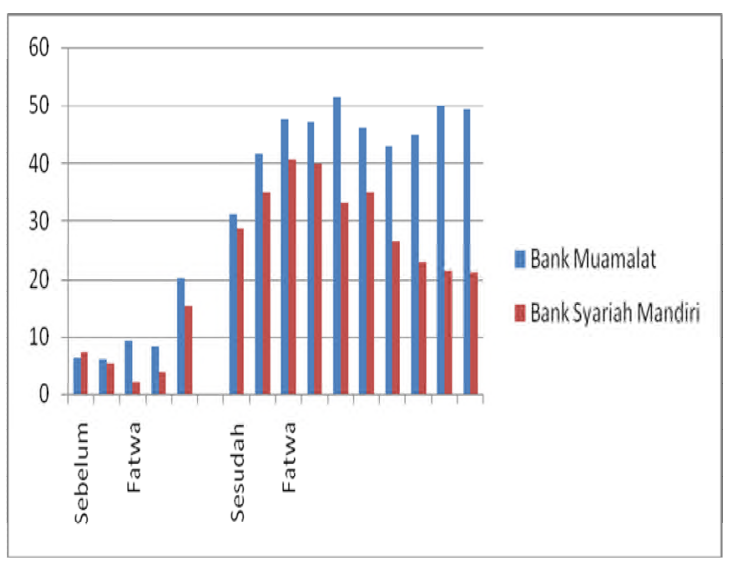

Sumber: Hasil Penelitian, 2016 (diolah)

Gambar 5.

Pertumbuhan Pembiayaan Mudharabah Musyarakah Bank Muamalat dan Bank Syariah Mandiri antara sebelum dan sesudah Fatwa MUI tentang haramnya bunga bank

Berdasarkan gambar 5

menunjukkan bahwa Bank Muamalat dan 
Rachmah, et al/Jurnal Ekonomi Syariah Teori dan Terapan Vol. 3 No. 12 Desember 2016: 973-988; ANALISIS PERBANDINGAN KINERJA KEUANGAN DAN EKONOMI SOSIAL BANK SYARIAH ANTARA SEBELUM DAN SESUDAH DITETAPKANNYA FATWA MUI TENTANG HARAMNYA BUNGA BANK

Bank Syariah Mandiri mengalami kenaikan dalam menyalurkan dana pembiayaan Mudharabah Musyarakah ke masyarakat ketika sesudah Fatwa MUI. Kebijakan ini sesuai dengan nilai-nilai Islam yang menganjurkan uang untuk selalu dialirkan. Hal tersebut sesuai dengan firman-Nya sebagai berikut:

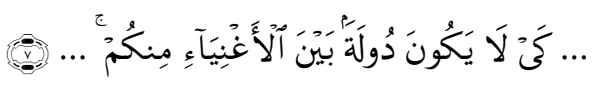

Artinya: "... supaya harta itu jangan beredar di antara orang-orang kaya saja di antara kamu..." (QS Al Hasyr ayat 7) (Departemen Agama RI, 2011:549)

Menurut tafsir Shihab (2004:212) menyatakan bahwa kaidah penataan sistem ekonomi Islam, yang mewakili salah satu bagian besar dari asas-asas ekonomi Islam. Sistem tersebut mengakui kepemilikan pribadi tetapi dibatasi oleh kaidah diatas, sehingga terhalang beredar di antara orang-orang kaya saja, salah satu upaya agar tidak beredar di orang-orang kaya saja adalah dengan pemberlakuan zakat dan pajak. Selain itu, pengharaman riba dan juga pengharaman menimbun juga termasuk dalam upaya agar tidak beredar di orang-orang kaya saja.

\section{SIMPULAN}

Berdasarkan analisis data dan pembahasan pada bab sebelumnya, dalam penelitian ini dapat diambil kesimpulan adalah pada kinerja Bank Syariah yang terdapat perbedaan signifikan antara sebelum dan sesudah Fatwa MUI tentang haramnya bunga bank terdapat pada rasio ROE, FDR, dan MMR. Hal ini menunjukkan bahwa dengan adanya Fatwa MUI tersebut membawa dampak positif bagi kinerja bagi syariah yakni rasio ROE, FDR dan MMR yang semakin lebih baik setelah adanya Fatwa MUI tentang haramnya bunga bank. Sedangkan pada rasio ROA dan CAR tidak terdapat perbedaan yang signifikan antara sebelum dan sesudah Fatwa MUI tentang haramnya bunga bank. Perbedaan tidak signifikan ini disebabkan oleh besarnya selisih rasio ROA dan CAR antara periode sebelum dan sesudah Fatwa MUI. Sehingga tidak terjadi peningkatan signifikan pada rasio ROA dan CAR ketika sesudah Fatwa MUI. Hal ini membuktikan bahwa dengan adanya Fatwa MUI tentang haramnya bunga bank dapat meningkatkan kinerja perbankan syariah di Indonesia dengan kinerja bank syariah yang baik maka dapat bersaing dengan bank syariah lainnya seiring dengan perkembangan bank syariah yang pesat di Indonesia.

Saran yang dapat direkomendasikan setelah melakukan penelitian kinerja bank syariah antara sebelum dan sesudah Fatwa MUI adalah sebagai berikut:

1. Untuk Bank Syariah, diharapkan dalam meningkatkan kinerja pada profitabilitas dengan cara mengelola dana dengan baik, karena dengan adanya dana yang besar namun tidak dikelola dengan baik justru akan menurunkan profitabilitas bank 
Rachmah, et al/Jurnal Ekonomi Syariah Teori dan Terapan Vol. 3 No. 12 Desember 2016: 973-988; ANALISIS PERBANDINGAN KINERJA KEUANGAN DAN EKONOMI SOSIAL BANK SYARIAH ANTARA SEBELUM DAN SESUDAH DITETAPKANNYA FATWA MUI TENTANG HARAMNYA BUNGA BANK

syariah. Dengan pengelolaan dana yang baik profitabilitas akan semakin meningkat sehingga kepercayaan masyarakat terhadap bank syariah semakin meningkat pula.

2. Bagi peneliti selanjutnya, diharapkan tidak hanya menganalisis kinerja kevangan dan kinerja ekonomi sosial Bank Umum Syariah di Indonesia tetapi bagaimana peran fungsi kinerja tersebut terhadap seluruh stakeholders.

\section{DAFTAR REFERENSI}

Ahyar, Gayo. 2011. Kedudukan Fatwa MUI Dalam Upaya Mendorong Pelaksanaan Ekonomi Syariah. Jakarta: Sinar Grafika.

Al-Jawziyyah, I.Q. 1995. I'lam alMuwaqqi'in. Kaherah.

Anshori, Muslich \& Sri Iswati. 2009. Metodologi Penelitian Kuantitatif. Surabaya: Airlangga University Press.

Antonio, Muhammad Syafi'i. 2001. Bank Syariah: Dari Teori Ke Praktik. Jakarta: Gema Insani Press.

Bayu, Kurniawan. 2014. Perbedaan Profitabilitas Bank Syariah Sebelum dan Sesudah Adanya Fatwa MUI Tentang Bunga Bank. Skripsi tidak diterbitkan. Malang: Universitas Islam Negeri Maulana Malik Ibrahim.

Beik, Irfan Syauqi. 2007. Bank Syariah dan Pengembangan Sektor Rill. Online, (www.pesantrenvirtual.com, diakses tanggal 25 November 2015).
Bungin, Burhan. 2005. Metodologi Penelitian Kuantitatif: Komunikasi, Ekonomi,

dan Kebijakan Publik serta Ilmu-llmu Sosial Lainnya. Jakarta: Prenada Media.

Cholil, Nafis. 2011. Teori Hukum Ekonomi Syariah. Jakarta: UI Press

Dendawijaya, Lukman. 2005. Manajemen Perbankan, edisi kedua. Jakarta: Ghalia Indonesia.

Dendawijaya, Lukman. 2009. Manajemen Perbankan. Ghalia Indonesia, Jakarta. Departemen Agama RI. 2005. Al-Qur'an dan Terjemahannya Special For Women. Bandung: Syaamul Al-Qur'an.

Terjemahannya. Surabaya: Pustaka Assalam.

Fadlli, M. Muhibbin. 2012. Analisis Perbandingan Kinerja Keuangan Bank Syariah Devisa dengan Bank Syariah Non Devisa dengan Menggunakan Metode CAMEL dan Shariah Conformity Indicator Periode 2009-2010. Skripsi tidak diterbitkan. Surabaya Fakultas Ekonomi dan Bisnis Universitas Airlangga Surabaya.

Fatih, Muhammad Nur. 2014. Perbandingan Kinerja Keuangan PT Bank Syariah Mandiri dan PT Bank Muamalat Indonesia. Skripsi tidak diterbitkan. Tulungagung Fakultas Ekonomi dan Bisnis Islam Institut Agama Islam Negeri (IAIN) Tulungagung.

Kusumo, Yunanto Adi. 2008. Analisis Kinerja Kevangan Bank Syariah Mandiri Periode 2002-2007 dengan Pendekatan 
Rachmah, et al/Jurnal Ekonomi Syariah Teori dan Terapan Vol. 3 No. 12 Desember 2016: 973-988; ANALISIS PERBANDINGAN KINERJA KEUANGAN DAN EKONOMI SOSIAL BANK SYARIAH ANTARA SEBELUM DAN SESUDAH DITETAPKANNYA FATWA MUI TENTANG HARAMNYA BUNGA BANK

PBI No. 9/1/2007. Jurnal Ekonomi Islam

La Riba, vol. II No. 1, Juli 2008.

Ma'ruf, Amin. 2008. Fatwa Dalam Sistem

Hukum Islam. Jakarta: Elsas.

Majelis Ulama Indonesia. 2004. Keputusan

Fatwa MUI Nomor I Tahun 2004

tentang Pelarangan Bunga Bank.

Jakarta: Majelis Ulama Indonesia.

Muhammad. 2011. Manajemen Bank

Syariah, Edisi Revisi Kedua. Yogyakarta:

Unit Penerbit dan Percetakan STIM YKPN.

P3El. 2012. Ekonomi Islam. Jakarta: Raja Grafindo Persada.

Republik Indonesia. Undang-undang Nomor 21 Tahun 2008 Tentang Perbankan Syariah. Jakarta: Bank Indonesia.

Ryandono, Muhammad. 2010. Peran dan Pengaruh Penghimpunan Dana dan Penyaluran Dana serta Kinerja Bank terhadap Kesejahteraan Karyawan Bank Islam Prespektif Maqashid Syariah di Indonesia. Disertasi tidak diterbitkan. Surabaya: Program Pasca Sarjana Universitas Airlangga.

Santoso, Singgih. 2010. Statistik Parametrik. Jakarta: PT. Elex Media Komputindo.

Sujarweni, V Wiratna. 2014. SPSS untuk Penelitian. Yogyakarta: Pustaka Baru Press.

Shihab, M. Quraish. 2002. Tafsir Al Misbah: Pesan, Kesan dan keserasian Al Qur'an Jilid 1: Jakarta: Lentera Hati.

Yuliani, Sinta. 2012. Analisis Pengaruh Kinerja Kevangan terhadap Kinerja Sosial Bank Umum Syariah di Indonesia tahun 2008-2010. Skripsi tidak diterbitkan. Depok: Universitas Indonesia. 